Tersedia Online di http://journal2.um.ac.id/index.php/jmsp/

ISSN Online : 2541-4429

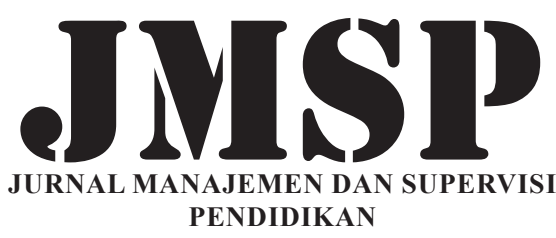

PENDIDIKAN

\title{
PROBLEMATIKA IMPLEMENTASI KURIKULUM 2013 DI SEKOLAH DASAR
}

\author{
Rina Wahyuni; Teti Berliani \\ Universitas Palangka Raya \\ Jl. Yos Sudarso Palangka Raya 74874 Indonesia \\ rina.wahyuni@mp.upr.ac.id
}

\begin{abstract}
Abtract: The purpose of this study is to: (1) describe the problem of teachers in designing learning implementation plans; (2) describe the problems in implementing scientific learning; and (3) describe problems in evaluating the affective and psychomotor domains. The approach used in conducting research is a qualitative approach, with a case study design. The results of the study show: (1) the problems in designing a plan for implementing learning are: (a) the teacher feels confused in formulating integrative thematic learning objectives; and (b) the teacher's lack of understanding in making learning plans oriented to 5M-based learning activities; (2) teacher problems in implementing learning based on scientific learning show: (a) the application of lecture methods and one-way communication from the teacher; (b) teachers are less than optimal in conducting class management; (c) lack of students' ability to read and write; and (d) lack of support and motivation from parents towards the development of children in school which results in the completion of school work carried out by parents so that children become irresponsible for their own work; and (3) the problem of teachers in conducting assessment of learning shows: (a) forms of assessment used in assessing student learning outcomes in the form of assessments in writing and verbally; and (b) the assessment conducted by the teacher focuses only on one aspect, namely the cognitive aspect.
\end{abstract}

Keyword: problematic, implementation, 2013 curriculum

\begin{abstract}
Abstrak: : Tujuan dilakukannya penelitian ini adalah untuk: (1) mendeskripsikan problematika guru dalam merancang rencana pelaksanaan pembelajaran; (2) mendeskripsikan problematika dalam mengimplementasikan scientific learning; dan (3) mendeskripsikan problematika dalam melakukan penilaian pada ranah afektif dan psikomotorik. Pendekatan yang digunakan dalam melakukan penelitian ialah pendekatan kualitatif, dengan rancangan studi kasus. Hasil penelitian menunjukkan: (1) problematika dalam merancang rencana pelaksanaan pembelajaran ialah: (a) guru merasa kebingungan dalam merumuskan tujuan pembelajaran yang bersifat tematik integratif; dan (b) ketidakpahaman guru dalam membuat rencana pembelajaran yang berorientasi pada kegiatan pembelajaran yang berbasis $5 \mathrm{M}$; (2) problematika guru dalam melaksanakan pembelajaran berbasis scientific learning menunjukkan: (a) penerapan metode ceramah dan komunikasi satu arah dari guru; (b) guru kurang optimal dalam melakukan manajemen kelas; (c) kurangnya kemampuan siswa dalam membaca dan menulis; serta (d) kurangnya dukungan dan motivasi dari orangtua terhadap perkembangan anak di sekolah yang berakibat pada penyelesaian tugas sekolah yang dilakukan oleh orangtua sehingga anak menjadi tidak bertanggungjawab akan pekerjaannya sendiri; serta (3) problematika guru dalam melakukan penilaian pembelajaran menunjukkan: (a) bentuk-bentuk penilaian yang digunakan dalam menilai hasil belajar siswa berupa penilaian secara tertulis dan secara lisan; dan (b) penilaian yang dilakukan guru hanya berfokus pada satu aspek saja yakni aspek kognitif.
\end{abstract}

Kata Kunci: problematika, implementasi, kurikulum 2013

Secara umum, peningkatan kualitas pendidikan selalu dimulai dari perbaikan sistem pendidikan yang akan dilaksanakan pada setiap tahunnya, salah satunya adalah melalui perbaikan kurikulum yang berlaku pada saat ini. Pada tahun 2004, kita diperhadapkan dengan KBK (Kurikulum Berbasis Kompetensi) yang berfokus pada pencapaian kompetensi yang harus diraih oleh siswa pada setiap pelajaran. Namun, jika dikaitkan dengan alat ukur kompetensi yang 
dimiliki siswa, KBK mendapat kerancuan yang begitu besar dikarenakan alat ukuryang digunakan dalam mengukur tingkat kompetensi siswa hanya bergantung pada hasil ujian nasional. Tidak bertahan lama dengan KBK, pada tahun 2006 Pemerintah kembali mengeluarkan kebijakan kurikulum baru yaitu KTSP (Kurikulum Tingkat Satuan Pendidikan).

Perbedaan antara KBK dan KTSP terlihat pada kebebasan guru-guru dalam merencanakan pembelajaran sesuai dengan lingkungan dan kondisi siswa serta kondisi sekolah berada. Kemudian pada tahun 2013, Pemerintah mengeluarkan Kurikulum 2013, dimana dalam proses pembelajarannya kurikulum ini lebih berfokus pada siswa sebagai subjek pembelajaran; siswa diharapkan lebih dominan dalam proses pembelajaran yang ada di kelas. Hal ini didasarkan pada suatu pandangan bahwa siswa memiliki potensi untuk berkembang dan berpikir mandiri, karena salah satu ciri pembelajaran efektif adalah mengembangkan pemikiran bahwa anak akan belajar lebih bermakna dengan cara bekerja sendiri, menemukan sendiri dan mengkonstruksi sendiri pengetahuan dan keterampilan barunya.

Pada Kurikulum 2013, guru dituntut sebagai fasilitator yang bertugas merangsang atau memberikan stimulus, membantu peserta didik untuk mau belajar sendiri dan merumuskan pengertiannya, sedangkan peran siswa adalah aktif dalam belajar dan mencerna pelajaran. Sejalan dengan itu, Poerwati dan Amri (2013) mengemukakan bahwa dalam Kurikulum 2013, guru diharapkan menggunakan berbagai macam metode belajar yang memungkinkan siswa untuk melatih berpikir, mentradisikan aktivitas kreatif, mengembangkan kemerdekaan berpikir, mengeluarkan ide, menumbuhkan kenikmatan bekerja sama sehingga guru dituntut menyediakan beragam kegiatan pembelajaran yang berimplikasi pada beragamnya pengalaman belajar agar siswa dapat mengembangkan kompetensinya secara mandiri.

Sehingga dengan demikian, sebagai seorang pendidik sudah seharusnya melakukan perencanaan pembelajaran yang lebih matang sebelum mengaplikasikannya di dalam kelas. Penyusunan rencana pembelajaran harus disesuaikan dengan kondisi siswa yang ada di kelas, selain itu juga harus memperhatikan keadaan sekitar sekolah dalam rangka guru mampu mengemas pembelajaran yang berlatar dan berfokus pada kehidupan siswa itu sendiri. Dengan adanya rencana pembelajaran yang matang, maka diharapkan guru dapat melaksanakan pembelajaran yang mampu mendorong dan merangsang siswa untuk mau terlibat aktif dalam proses pembelajaran di kelas; sehingga siswa mampu diajak untuk berpikir aktif dalam membangun dan mengembangkan kemampuannya dalam berkreativitas dan berinovasi dalam pembelajaran yang dipelajarinya.

Keaktifan, kreativitas dan inovasi siswa dalam pembelajaran pun menjadi salah satu target utama guru dalam melakukan penilaian terhadap siswa. Karena dalam Kurikulum 2013, guru tidak hanya menilai siswa secara kognitifnya saja, melainkan penilaian juga dilakukan pada aspek sikap dan keterampilan siswa saat mengikuti pembelajaran di kelas. Sehingga kemampuan siswa tidak hanya dilihat dan dinilai dari aspek kemampuannya secara pengetahuan, tetapi juga secara kreativitas, inovasi bahkan sikap serta akhlak siswa dalam mengikuti proses pembelajaran di sekolah.

Akan tetapi, begitu banyak problematika yang dialami guru dalam mengimplementasikan kurikulum 2013, yaitu:(1)kemampuan guru dalam menyusun rencana pelaksanaan pembelajaran (RPP) berdasarkan ketentuan dan format yang sudah ada dirasa masih sangat kurang; (2) kemampuan guru dalam mengimplementasikan pembelajaran yang berbasis scientific learning juga masih belum maksimal dikarenakan pemahaman guru masih pada tataran awal (kulitnya saja) dan guru juga masih menggunakan metode pembelajaran tradisional; serta (3) kemampuan guru dalam melakukan penilaian yang sampai saat ini masih terbatas pada aspek kognitif sehingga mengabaikan aspek afektif dan psikomotorik siswa.

Hal itu tentu sangat bertolak belakang dengan yang diharapkan dalam penerapan Kurikulum 2013. Pemerintah mengharapkan, dalam penerapan kurikulum 2013, guru harus memiliki kemampuan dalam: (1) menyusun RPP yang mampu mengajak dan menarik agar siswa 
mau terlibat aktif dalam proses pembelajaran; (2) melaksanakan proses pembelajaran yang berlandaskan pada scientific lelarning dimana pembelajaran berfokus pada kegiatan $5 \mathrm{M}$, yaitu: mengamati, menanya, menalar, mencoba, dan mengkomunikasikan; serta (3) melakukan evaluasi pembelajaran yang berfokus pada 3 aspek, yaitu: kognitif, afektif dan psikomotorik. Sehingga sebagai seorang pendidik professional, guru dituntut untuk berpikir, bertindak dan bertutur secara professional pula terlebih dalam menghadapi siswa pada proses pembelajaran.

\section{METODE}

Penelitian ini menggunakan pendekatan kualitatif dengan rancangan studi kasus; karena peneliti melakukan penelitian dengan menggunakan satu lembaga pendidikan sebagai kasus yang akan diteliti. Lokasi penelitian dilakukan pada Sekolah Dasar Negeri (SDN) 6 Bukit Tunggal Kota Palangka Raya. Pemilihan informan yang menjadi sumber data dilakukan dengan teknik purposive sampling dan snowball sampling. Prosedur dalam pengumpulan data dilakukan dengan 3 cara, yaitu: (1) observasi; (2) wawancara mendalam; dan (3) studi dokumentasi. Teknik analisis data yang digunakan dalam penelitian ini menggunakan pola interaktif dari Miles, Huberman dan Saldana (2014) yang meliputi proses pengumpulan data, kondensasi data, penyajian data dan penarikan kesimpulan.

Kemudian dalam prosedur pengecekan keabsahan data digunakan 3 tahap, yakni: (1) kredibilitas, yang terdiri dari triangulasi, member check dan kecukupan bahan referensi; (2) dependabilitas, yang dilakukan oleh peneliti mulai dari melakukan penelitian, penyusunan transkrip wawancara sampai dengan penulisan laporan hasil penelitian dan pelaksanaan penelitian sesuai dengan jadwal yang telah disepakati bersama; serta (3) konfirmabilitas, dilakukan dengan cara memeriksa kembali seluruh catatan lapangan dan data hasil penelitian di lapangan secara berulangulang sambil mencocokkan kembali dengan data yang mendukungnya; kemudian dilakukan dengan pembenaran dari kepala sekolah bahwa peneliti benar-benar telah melakukan penelitian pada sekolah yang dipimpinnya serta adanya pengantar surat ijin melakukan penelitian ilmiah dari Dekan Fakultas Keguruan dan Ilmu Pendidikan Universitas Palangka Raya dan surat keterangan telah melakukan penelitian dari lembaga pendidikan yang menjadi lokasi penelitian, yakni SDN 6 Bukit Tunggal Kota Palangka Raya.

\section{HASIL}

Hasil penelitian dari studi kasus penelitian yang telah dilakukan, dirumuskan dan dirangkum dalam bentuk pernyataan-pernyataan yang disesuaikan dengan fokus penelitian yang ada sebagai berikut.

\section{Problematika dalam Merancang Rencana Pelaksanaan Pembelajaran (RPP)}

Hasil temuan penelitian tentang problematika dalam merancang rencana pelaksanaan pembelajaran menunjukkan: (1) guru merasa kebingungan dalam merumuskan tujuan pembelajaran yang bersifat tematik integratif sehingga seringkali saat pelaksanaannya dalam kelas lebih condong ke satu mata pelajaran saja; dan (2) ketidakpahaman guru dalam membuat rencana pembelajaran yang berorientasi pada kegiatan pembelajaran yang berbasis mengamati, menalar, mencoba, menanya, dan mengkomunikasikan.

\section{Problematika Guru dalam Melaksanakan Pembelajaran Berbasis Scientific Learning}

Hasil temuan penelitian tentang problematika guru dalam melaksanakan pembelajaran berbasis scientific learning menunjukkan: (a) penerapan metode ceramah dan komunikasi satu arah dari guru mengakibatkan anak didik menjadi pasif; (b) masih ditemukan guru yang belum pernah diikutsertakan dalam pelatihan terkait penerapan kurikulum 2013, sehingga secara teknis di kelas guru hanya mengandalkan informasi yang diperolehnya dari rekan sejawat yang telah mengikuti pelatihan maupun dari internet; (c) guru kurang optimal dalam melakukan manajemen kelas pada siswa didiknya khususnya siswa kelas rendah (kelas 1); (d) kurangnya kemampuan siswa dalam membaca dan menulis menjadi masalah bagi guru dalam menyampaikan pembelajaran di dalam kelas sehingga siswa cenderung pasif serta hanya mendengarkan saja; serta (e) kurangnya dukungan dan motivasi 
dari orangtua terhadap perkembangan anak di sekolah yang berakibat pada penyelesaian tugas sekolah yang dilakukan oleh orangtua sehingga anak menjadi tidak bertanggung jawab akan pekerjaannya sendiri.

\section{Problematika Guru Dalam Melakukan Penilaian Pembelajaran}

Hasil temuan penelitian yang berkenaan tentang problematika guru dalam melakukan penilaian pembelajaran menunjukkan: (1) bentuk-bentuk penilaian yang digunakan dalam menilai hasil belajar siswa berupa penilaian secara tertulis sederhana seperti membuat puisi sederhana dengan kata-kata sendiri; kemudian penilaian secara lisan dilakukan dengan Tanya jawab sederhana secara satu arah (dari guru ke siswa); (2) ketidakaktifan siswa dalam mengikuti pembelajaran yang diberikan oleh guru yang diakibatkan ketidaklancaran siswa dalam membaca maupun menulis; dan (3) penilaian yang dilakukan guru hanya berfokus pada satu aspek saja yakni aspek kognitif, sedangkan untuk aspek afektif dan psikomotorik hanya sebatas pada melakukan penilaian berdasarkan hasil pengamatan terhadap tingkah laku siswa di sekolah.

\section{PEMBAHASAN}

Permasalahan yang ditemukan dalam temuan penelitian diatas, sejalan dengan pendapat Suryadi (2013) yang mengatakan bahwa peleburan beberapa mata pelajaran akan menimbulkan masalah terutama terkait keberadaan guru; ketika mata pelajaran dileburkan dan integrasikan, banyak guru yang sudah menjadi guru profesional kehilangan pekerjaan. Bahkan tidak bisa lagi menerima tunjangan profesi karena jam mengajarnya tidak cukup. Di samping itu, apa yang disebut pendekatan tematik integratif ini diakui banyak pihak sangat memberatkan guru. Begitu juga dengan pedoman kolaborasi kontekstual dan praktek yang tidak dirincikan dalam implementasi kurikulum 2013. Ini akan berpotensi merugikan siswa dan membingungkan guru. Sejalan dengan itu, Iskandar (2013) melalui kunjungan kerjanya ke Kalimantan Timur dan Sulawesi Selatan menemukan bahwa para guru baru memahami kulitnya saja dan belum menguasai isi Kurikulum 2013 sehingga memberatkan siswa dan membingungkan guru.
Lebih lanjut, Sanjaya (2009) mengatakan tidak dapat dipungkiri bahwa guru merupakan salah satu faktor penting dalam implementasi kurikulum; namun bagaimanapun sempurnanya sebuah kurikulum yang dirancang, tanpa ditopang oleh kemampuan guru untuk mengimplementasikannya, kurikulum yang telah dirancang dengan bagus itu akan sia-sia. (dalam Ahmad, 2014). Sama halnya dengan yang diungkapkan oleh Sonhadji (2013) bahwa ketika guru kurang mampu mentransformasikan acuan pokok dalam pembelajaran dapat menyebabkan guru tersebut akan kehilangan arah dan secara serampangan dalam menentukan isi kurikulum yang diajarkannya. Sehingga sudah sangat jelas, ketika guru tersebut belum mampu dalam memahami apa yang diinginkan oleh kurikulum yang ada maka guru tidak akan mampu merefleksikan isi kurikulum ke dalam jabaran atau sebaran pembelajaran yang akan diajarkan; dan inipun akan berakibat pada kesalahan dalam menyampaikan pembelajaran ke siswa didik serta membuat siswa didik memperoleh pembelajaran yang tidak sesuai dengan yang seharusnya.

Temuan penelitian yang berkenaan dengan penggunaan metode ceramah dan komunikasi satu arah yang hanya dari guru ke siswa berakibat pada ketidakaktifan siswa dalam mengikuti pembelajaran yang ada. Hal itu sejalan dengan yang dikatakan oleh Sonhadji (2013) bahwa memang pada kenyataannya masih banyak guru yang memberikan pembelajaran secara satu arah dalam bentuk ceramah dan instruksiinstruksi untuk mengerjakan sesuatu kepada siswa sehingga menjadikan siswa kurang kreatif, kurang mandiri, dan bersikap pasif. Ditambah lagi dengan kurangnya kemampuan siswa dalam membaca dan menulis yang menjadi salah satu penyebab ketidakoptimalan siswa dalam mengikuti pembelajaran dengan baik di kelas.

Padahal seyogianya, anak yang sudah memasuki pendidikan dasar memiliki kemampuan untuk membaca dan berhitung dasar yang sederhana sebagai bekal dalam menempuh pendidikan pada jenjang dasar tersebut. Namun dari hasil penelitian yang diperoleh sangatlah bertolak belakang dengan apa yang diungkapkan oleh Sonhadji (2013) bahwa salah satu konsep yang berkaitan dengan belajar dasar adalah keterampilan dasar (basic skills), yaitu kemampuan minimal yang harus dimiliki oleh 
peserta didik agar dapat terus mengembangkan dirinya. Ballantine (Sonhadji, 2013) mengamati bahwa kelemahan dalam keterampilan dasar (membaca, menulis, dan matematika) serta kurangnya persiapan membawa peserta didik pada risiko ketika memasuki dunia pendidikan.

Kurang optimalnya guru dalam melakukan manajemen kelas juga berakibat pada kurang terciptanya kondisi dan situasi belajar yang kondusif serta menyenangkan yang memungkinkan kegiatan belajar mengajar bisa berjalan dengan baik sesuai perencanaan dan mencapai tujuan yang telah ditetapkan dalam rencana pembelajaran. Hasil penelitian tersebut sangat bertolak belakang dengan yang diungkapkan oleh Sagala (2012) bahwa kondisi proses belajar mengajar yang berlangsung optimal harus direncanakan dan diusahakan oleh guru secara sengaja agar dapat dihindarkan dari kondisi dan situasi yang merugikan/mengganggu jalannya proses pembelajaran di dalam kelas. Keberhasilan guru dalam mengelola kelas dengan baik juga dapat terlihat dari tingkat keaktifan siswa dalam mengikuti pembelajaran yang diberikan guru.

Sehingga sependapat dengan yang diungkapkan oleh Hasibuan (Sagala, 2012), jika pengaturan kondisi pendukung belajar dapat dikerjakan secara optimal, maka proses belajar mengajar pun akan berlangsung secara optimal pula. Selain manajemen kelas yang baik, seorang guru juga senantiasa melakukan hubungan komunikasi yang baik dengan para orangtua siswa. Hal ini dilakukan agar orangtua memiliki kepedulian terhadap pendidikan dan perkembangan anaknya di sekolah. Kurangnya dukungan dan motivasi dari orangtua terhadap perkembangan anak di sekolah yang berakibat pada kurangnya rasa memiliki dan tanggung jawab yang dimiliki orangtua terhadap pendidikan dan perkembangan anak di sekolah.

Tentunya hal itu sangat bertolak belakang dengan yang dikatakan Hermino (2014) bahwa dalam menjalin hubungan antara lembaga pendidikan dan masyarakat maka harus terjadi proses komunikasi dengan tujuan meningkatkan pemahaman masyarakat terhadap kebutuhan dan praktik pendidikan dan pada akhirnya saling bekerja sama untuk meningkatkan pemahaman masyarakat terhadap kebutuhan dan praktik pendidikan untuk meningkatkan kualitas pendidikan itu sendiri. Lebih lanjut, Hermino (2014) menegaskan bahwa tujuan dari hubungan yang baik antara lembaga pendidikan dengan masyarakat ialah untuk meningkatkan efektivitas dan efisiensi kegiatan sekolah dalam memajukan kualitas pertumbuhan dan perkembangan proses belajar peserta didik, memajukan kualitas kehidupan masyarakat dan mengembangkan pengertian serta minat masyarakat terhadap program kegiatan dilembaga pendidikan.

Temuan penelitian yang berkaitan dengan bentuk tes yang digunakan dalam penilaian proses pembelajaran sejalan dengan yang diungkapkan oleh Poerwati dan Amri (2013) bahwa untuk mengetahui tingkat pencapaian kompetensi anak didik, guru dapat melakukan penilaian melalui tes dan non tes; yang meliputi: (a) tes, terdiri dari tes lisan, tertulis, dan tes perbuatan; sedangkan (b) penilaian non tes, terdiri atas penilaian sikap, minat, motivasi, penilaian diri, portofolio, dan life skills serta melakukan tes perbuatan melalui pengamatan (observasi). Sejalan dengan itu, Masaong (2013) juga berpendapat bahwa dalam melakukan penilaian sikap anak didik dapat dilakukan dengan beberapa cara antara lain: (a) observasi perilaku, (b) pertanyaan langsung, dan (c) laporan pribadi. Dari hasil penelitian, guru lebih cenderung melakukan penilaian dari aspek kognitif saja dan cenderung mengabaikan aspek afektif dan psikomotorik. Guru sudah melakukan penilaian terhadap sikap siswa yang didasarkan pada pengamatan kesopanan siswa saat berada di sekolah sehingga secara tidak langsung, gurupun sudah melakukan penilaian pada aspek afektif meskipun dalam lingkup yang sempit.

\section{SIMPULAN}

Berdasarkan keseluruhan paparan data, temuan penelitian dan pembahasan hasil penelitian, dapat dikemukakan kesimpulan penelitian sebagai berikut.

1. Problematika dalam Merancang Rencana Pelaksanaan Pembelajaran (RPP) dapat dikategorikan masih perlu pembimbingan dan pembinaan yang lebih intensif terhadap perancangan rencana pelaksanaan pembelajaran yang dilakukan oleh guru. Hal ini dikarenakan guru masih belum memahami dengan benar terkait penerapan kurikulum 2013 terlebih dalam merumuskan tujuan pembelajaran yang bersifat 
tematik integratif dimana tujuan pembelajaran dari beberapa mata pelajaran diintegrasikan menjadi satu dan dilaksanakan dalam waktu yang bersamaan pula.

2. Problematika guru dalam melaksanakan pembelajaran berbasis scientific learning dapat dikatakan masih belum optimal, hal ini dikarenakan: (a) guru masih menggunakan metode pembelajaran tradisional yaitu ceramah; (b) masih ada guru yang belum pernah mengikuti kegiatan pelatihan yang berkenaan dengan penerapan kurikulum 2013; (c) kurang optimalnya guru dalam melakukan manajemen kelas; serta (d) kurangnya motivasi dan dukungan dari orangtua siswa terkait perkembangan ankanya di sekolah.

3. Problematika guru dalam melakukan penilaian pembelajaran masih belum sesuai dengan kriteria yang terdapat dalam ketentuan Kurikulum 2013 karena kategori yang digunakan guru masih terlalu sederhana sehingga belum optimal dalam mencapai tujuan pembelajaran yang ada. Dan guru lebih cenderung hanya menilai pada satu aspek saja, yaitu aspek kognitif siswa.

\section{DAFTAR RUJUKAN}

Ahmad. 2014. Problematika Kurikulum 2013 dan Kepemimpinan Instruksional Kepala Sekolah. Jurnal Pencerahan, 8(2): 98-108.

Bogdan, R. C., dan Biklen, S. K. 1992. Qualitative Research for Education. USA: Allyn and Bacon.

Fatchan, A. 2005. Konsep dan Metode Penelitian Kualitatif. Malang: Prodi Pendidikan Geografi PPs UM.

Ghony, D., dan Almanshur, F. 2012. Metodologi Penelitian Kualitatif. Jogjakarta: AR-RUZZ MEDIA.
Hermino. 2014. Manajemen Kurikulum Berbasis Karakter. Bandung: Alfabeta.

Kamus Besar Bahasa Indonesia. 2018. Jakarta: Puskurbuk Kemdikbud.

Mantja, W. 2007. Etnografi: Desain Penelitian Kualitatif Pendidikan dan Manajemen Pendidikan. Malang: ELANG MAS.

Masaong, A. K. 2013. Supervisi Pembelajaran dan Pengembangan Kapasitas Guru. Bandung: Alfabeta.

Miles, Huberman, dan Saldana. 2014. Qualitative Data Analysis A Methods Sourcebook. United States of America: SAGE Publications Inc.

Poerwati, dan Amri. 2013. Panduan Memahami Kurikulum 2013. Jakarta: PT Prestasi Pustakaraya.

Sagala. 2012. Administrasi Pendidikan Kontemporer. Bandung: Alfabeta.

Satori, D., dan Komariah, A. 2013. Metodologi Penelitian Kualitatif. Bandung: Alfabeta.

Sonhadji, A., Thoyib, A., Sunyoto, A., Furchan, A., Santoso, M., Arifin, S. M., dan Arifin, I. 1996. Penelitian Kualitatif dalam Ilmu-Ilmu Sosial dan Keagamaan. Malang: Kalimasahada Press.

Sonhadji. 2013. Manusia, Teknologi dan Pendidikan Menuju Peradaban Baru. Malang: UM Press.

Sugiyono. 2012. Metode Penelitian Kuantitatif, Kualitatif dan RdanD. Bandung: Alfabeta.

Ulfatin, N. 2014. Metode Penelitian Kualitatif di Bidang Pendidikan: Teori dan Aplikasinya. Malang: Bayumedia Publishing.

Undang-undang Republik Indonesia Nomor 20 tahun 2003 tentang Sistem Pendidikan Nasional. Jakarta: Fokus Media.

Wiyono, B. B. 2007. Metodologi Penelitian (Pendekatan Kuantitatif, Kualitatif, dan Action Research). Malang: FIP Universitas Negeri Malang. 